Journal of the Indonesian Tropical Animal Agriculture

(J. Indonesian Trop. Anim. Agric.)

pISSN 2087-8273 eISSN 2460-6278

41(3):117-124, September 2016

DOI: $10.14710 /$ jitaa.41.3.117-124

\title{
SAPU-SAPU FISH (Hyposarcus pardalis) AS A SINGLE PROTEIN SOURCE FOR LAYING MOJOSARI DUCKS
}

\author{
B. Indarsih, Asnawi and D. K. Purnamasari \\ Faculty of Animal Science, Mataram University, Lombok, NTB, 83125 - Indonesia \\ CorrespondingE-mail:budiindarsih@unram.ac.id
}

Received April 11, 2016; Accepted June 20, 2016

\begin{abstract}
ABSTRAK
Penelitian ini dilakukan untuk mengevaluasi bentuk penyajian dan level optimum ikan sapu-sapu (ISS) sebagai sumber protein tunggal untuk komponen pakan itik Mojosari yang dipelihara pada skala kecil. Sebanyak 180 ekor itik petelur umur 24 minggu diberi pakan ISS bentuk kering sinar matahari dan giling segar dengan tiga level (10,20 dan 30\%) dari umur 24 sampai 32 minggu. Pakan diformula mengandung protein 105,1; 141,5 dan 177,9 g/kg dengan metabolisme energi 3078; 3065 dan 3052 $\mathrm{kkal} / \mathrm{kg}$ pakan. Parameter yang diukur adalah performan produksi dan kualitas telur. Bentuk penyajian ISS berpengaruh sangat nyata $(\mathrm{P}<0.0001)$ terhadap konsumsi pakan, produksi telur, konversi pakan, berat massa telur, dan jumlah telur kecuali bobot badan akhir. Tidak ada pengaruh nyata $(\mathrm{P}>0.05)$ terhadap semua parameter produksi yang diukur kecuali konsumsi pakan dan bobot badan akhir. Bentuk penyajian dan level ISS menunjukkan interaksi $(\mathrm{P}<0.05)$ terhadap bobot telur dan bobot badan. Performan dan kualitas telur rendah pada itik yang diberi ISS kering. Itik lokal dapat dinyatakan memerlukan $20 \%$ ISS sebagai sumber protein tunggal untuk produksi telur maksimum (41.2\%) dengan jumlah telur per minggu (3.1 butir/ekor/minggu) selama 8 minggu pemeliharaan. Kualitas telur lebih baik dengan menggunakan ISS segar. Namun, dengan teknik pengolahan yang baik, ISS kering mempunyai potensi seperti tepung ikan konvensional untuk itik petelur.

Kata kunci: produksi dan kualitas telur, ikan sapu-sapu, itik Mojosari
\end{abstract}

\begin{abstract}
The present study was conducted to evaluate the optimum level of dietary inclusion and the form of feeding sapu-sapu fish (SSF) as a single protein source for feed components of small holder Mojosari duck farming. A total of 180 twenty four wk-old laying ducks were fed with two forms (sun-dried and ground-fresh) and three levels of SSF (10,20 and 30\%) from 24 to $32 \mathrm{wk}$ of age. Experimental diets were formulated containing $105.1 ; 141.5$ and $177.9 \mathrm{~g} / \mathrm{kg}$ crude protein and $3078 ; 3065$ and $3052 \mathrm{kcal}$ metabolizable energy (ME) $/ \mathrm{kg}$ diet. Production performance and egg quality were measured. The form of SSF had a significant effect $(\mathrm{P}<0.0001)$ on feed intake, egg production, feed conversion, egg mass and egg number except final body weight. No significant effects $(\mathrm{P}>0.05)$ were found on all of the performance parameters measured due to feeding levels of SSF except feed intake and final body weight. The interaction of form and feeding level was significant $(\mathrm{P}<0.05)$ on egg and body weights. Low performance and egg quality were observed in the birds fed a diet containing the dried SSF. It can be suggested that local ducks required $20 \% \mathrm{SSF}$ as a single protein source for maximum egg production $(41.2 \%)$ and total egg number per wk (3.1 eggs/bird/wk) during $8 \mathrm{wk}$ of rearing period. Egg quality can be improved by feeding the fresh SSF. However, due to be sufficiently better processing technique, the dried SSF would be potential to replace the common fish for laying ducks.
\end{abstract}

Keywords: egg production and quality, sapu-sapu fish, Mojosari duck 


\section{INTRODUCTION}

Common fish meal (CFM) have been known to be an excellent protein source for poultry because of its complete essential amino acids although it has low fat and calorie contents (Wimalasena and Jayasuriya, 1996; Thongwittaya, 2007). Until the present time, CFM is too expensive and unaffordable for most small scale farmers. Some studies have been carried out to replace fish meal in part or complete substitution with other protein sources such as groundnut cake and blood meal (Onwudike, 1981), shrimp waste (Dong et al., 2005), grasshopper (Hassan et al., 2009), shrimps and marine waste (Aktar et al., 2011), and sesame seed cake (Falayi et al., 2013). However, such efforts were not significantly successful, due to the level-dependent of substitution (Aktar et al., 2011) and also other protein sources used in the feed formulation.

Mojosari ducks are one of the local laying waterfowl breeds in Indonesia and very popular breed for their high egg production. However, because of the high commercial feed cost, most of local farmers fed their ducks with the alternative animal protein source such as ground fresh sapusapu fish (SSF) (Hyposarcus pardalis) as a substitution for fish meal. Based on our proximate analysis using the procedure of AOAC (1990), dry matter, crude protein, ether extract, crude fibre, and ash of SSF were 96.28, 42.49, 14.38, 10.99, and $26.66 \%$ respectively. Whilst fish meal according to NRC (1994), depending on the variety of fish, contains dry matter, crude protein, ether extract, and crude fiber in the range of 92.0$93.0,60.05-64.2,5.0-10.0,0.7-1.0 \%$ respectively and no ash information was available. SSF is a fresh water fish and easily available grows in the polluted environments of river water (Roosmini et al., 2006).

A preliminary study conducted by the author revealed that production performance of layer ducks during the second laying production period was relatively high when a combination of ground fresh SSF with rice bran and yellow corn was fed. However, this ground fish is a highly perishable and rapidly spoiled make it possible to be easily broken by the microorganisms. When an excessive feeding practice was applied, it will create odor problems. Therefore, the present study was undertaken to assess different forms and levels of SSF on productive performance and egg quality of laying Mojosari ducks.

\section{MATERIALS AND METHODS}

\section{Material and Management}

A total of 180 24-wk-old laying Mojosari ducks were obtained from the local breeder and distributed into a completely randomized design in a $2 \times 3$ factorial arrangement. They were then weighed, wing-banded individually and reared in grouped-housed in an intensively ban from bamboo. Two forms (ground fresh and sun dried) and three levels of sapu-sapu fish $(10,20$ and $30 \%$ ) were formulated as the treatment diets. Each treatment was replicated in six times with 5 birds per replicate. Diets were based on yellow corn and rice bran (Table 1) and fed from 24 to $32 \mathrm{wk}$ of age. Feeding method was restricted to 190 $\mathrm{g} / \mathrm{bird} / \mathrm{d}$ and provided twice a day $(6.00 \mathrm{am}$ and $5.00 \mathrm{pm}$ ) to avoid the over spilling feed. The diets were provided in a slurry form. Spillage of the feed was calculated by weighing and drying the remaining feed on the feeder and drinking water to correct the feed intake. Each pen was made from bamboo and had an area of $1 \times 0.85 \mathrm{~m}$ for the floor space with rice hulls as the litter. The pens were equipped with one rounded plastic feeders with $20 \mathrm{~cm}$ in diameter. Routine management practices such as health and disease control programs were applied. The ducks were again individually weighed on the last day of the study.

\section{Parameters}

The data on feed intake, egg production and egg weight were recorded daily. Feed conversion ratio (g feed/g egg) and egg mass ( $\mathrm{g} / \mathrm{hen} / \mathrm{day})$ were calculated. The external and internal qualities of eggs laid by ducks were measured on wk 7 , and 8 of the experimental production period for two consecutive days. A total number of 288 eggs (72 eggs per collection) were taken and broken out on a clean Petri dish. Shell thickness, shell weight, albumen weight and albumen height, yolk weight and yolk height were analyzed and then yolk color was measured against the Roche Yolk Color Fan scale (RYCF) as a tool for a standard colors ranging from 1 (the lightest) to 15 (the darkest). This work was carried out at the Laboratory of Animal Product Processing Technology- Faculty of Animal Science, Mataram University.

\section{Statistical Analysis}

Data were analysed by ANOVA according to the General Linear Model procedure of SAS software (SAS, 1999) for a completely 
Table 1. Ingredient and Nutrient Composition $(\mathrm{g} / \mathrm{kg})$ of Experimental Diets

\begin{tabular}{|c|c|c|c|}
\hline \multirow{2}{*}{ Ingredient $\mathrm{g} \mathrm{kg}^{-1}$} & \multicolumn{3}{|c|}{ Dietary treatment } \\
\hline & $\mathrm{T} 1$ & $\mathrm{~T} 2$ & $\mathrm{~T} 3$ \\
\hline Rice bran (RB) & 600 & 500 & 400 \\
\hline Yellow corn (YC) & 300 & 300 & 300 \\
\hline Sapu-sapu fish (SSF) & 100 & 200 & 300 \\
\hline Total & 1,000 & 1,000 & 1,000 \\
\hline \multicolumn{4}{|l|}{ Calculated nutrients } \\
\hline Metabolizable energy, $\mathrm{kcal} \mathrm{kg}^{-1}$ & 3,078 & 3,065 & 3,052 \\
\hline Crude protein, $\mathrm{g} \mathrm{kg}^{-1}$ & 105.10 & 141.50 & 177.90 \\
\hline Crude fiber, $\mathrm{g} \mathrm{kg}^{-1}$ & 135.50 & 119.00 & 100.90 \\
\hline Ether extract, $\mathrm{g} \mathrm{kg}^{-1}$ & 41.20 & 52.60 & 63.90 \\
\hline Ash, $\mathrm{g} \mathrm{kg}^{-1}$ & 141.70 & 150.10 & 158.60 \\
\hline Calcium, $\mathrm{g} \mathrm{kg}^{-1}$ & 1.07 & 1.84 & 2.62 \\
\hline Available phosphorus, $\mathrm{g} \mathrm{kg}^{-1}$ & 0.53 & 0.59 & 0.66 \\
\hline
\end{tabular}

No vitamin and mineral added

T1: $10 \% \mathrm{SSF} ; \mathrm{T} 2: 20 \% \mathrm{SSF} ; \mathrm{T} 3=30 \% \mathrm{SSF}$

randomized design with a factorial arrangement. The independent variables were form and levels of SSF. The differences between the means of groups were identified by Tukey's Test with the significant levels of $\mathrm{P}<0.05$.

\section{RESULTS AND DISCUSSION}

\section{Production Performance}

Production performance (Table 2) showed that the form had a significant effect $(\mathrm{P}<0.0001)$ on all parameter measured except final body weight. Whilst the levels of SSF did not affect $(\mathrm{P}>0.05)$ bird's performance except feed intake and body weight. There was a significant interaction $(\mathrm{P}<0.05)$ between the two evaluated factors only on egg weight and body weight.

Overall, the birds consuming a diet containing the dried SSF resulted in low production performance. Lower feed intake, egg production, egg weight, total egg number, egg mass and poor FCR of the birds fed with the dried SSF than that of the fresh. This may be related to the natural feeding habit of ducks with the fresh and wet feeds. In addition, imperfect sun-drying in this study could also be responsible to the low production performance. A study of Akintola et al. (2013) showed the lowest amino acid in sundried process of giant tiger shrimp. Sun-dried fish was responsible to the fat loss (Akinwumi et al., 2011), protein loss (Jeyasanta et al., 2014) and more susceptible to microbial invasion (Akinwumi et al., 2011) due to improper drying.

The effect of different levels of SSF on feed intake and body weight was significant but other parameters numerically showed higher values in higher ISS levels. The birds fed higher SSF (30\%) which provide the higher dietary protein (177.9 $\mathrm{g} / \mathrm{kg}$ ) showed significantly the lower feed intake $(122.6 \mathrm{~g} / \mathrm{bird} / \mathrm{d})$ than the higher feed intake values of $130.7,137.1 \mathrm{~g} / \mathrm{bird} / \mathrm{d}$ for birds on lower SSF (20\% and $10 \%)$ diets. However, increasing SSF levels from 10 to $30 \%$ increased protein intake from 15.2 to $24.3 \mathrm{~g} / \mathrm{bird} / \mathrm{d}$ (Table 3 ) and improved body weight inconsistently. The highest values of body weight was on the $30 \%$ SSF $(1.53 \mathrm{~kg} /$ bird $)$. In contrast, Bunchasak et al. (2005) showed that hens fed with the $16 \%$ CP diet had higher feed intake than the $14 \%$ CP diet. Since the present study formulated the high protein diet with low ME whilst Bunchasak et al. (2005) used a high ME diet, birds fed on high protein diet, the voluntary feed intake is solely triggered by the low energy content in the diet. 
Table 2. The Effect of Forms and Levels of SSF on Productive Performance of Mojosari Ducks From 24 to $32 \mathrm{Wk}$ of Age

\begin{tabular}{|c|c|c|c|c|c|c|c|c|}
\hline $\begin{array}{l}\text { SSF } \\
\text { Form }\end{array}$ & $\begin{array}{c}\text { SSF } \\
\text { Level } \\
(\%)\end{array}$ & $\begin{array}{c}\text { Feed } \\
\text { Intake }(\mathrm{g})\end{array}$ & $\begin{array}{l}\text { Egg } \\
\text { Production } \\
\quad(\%)\end{array}$ & $\begin{array}{c}\text { FCR } \\
(\mathrm{g} \mathrm{feed} / \mathrm{g} \\
\text { egg) }\end{array}$ & $\begin{array}{c}\text { Egg } \\
\text { Weight } \\
\text { (g) }\end{array}$ & $\begin{array}{c}\text { Total Egg } \\
\text { Number/ } \\
\text { Bird/wk } \\
\text { (eggs) }\end{array}$ & $\begin{array}{l}\text { Egg Mass } \\
\text { (g/bird/d) }\end{array}$ & $\begin{array}{l}\text { Body } \\
\text { Weight } \\
\text { (gram) }\end{array}$ \\
\hline Dried & & $121.9^{\mathrm{b}}$ & $29.0^{\mathrm{b}}$ & $6.807^{\mathrm{a}}$ & $55.6^{\mathrm{b}}$ & $2.4^{\mathrm{b}}$ & $16.30^{\mathrm{b}}$ & 1456 \\
\hline Fresh & & $138.4^{\mathrm{a}}$ & $50.7^{\mathrm{a}}$ & $4.223^{\mathrm{b}}$ & $62.0^{\mathrm{a}}$ & $3.5^{\mathrm{a}}$ & $31.48^{\mathrm{a}}$ & 1479 \\
\hline \multirow[t]{4}{*}{ Pooled SEM } & & 1.5 & 1.87 & 0.284 & 1.19 & 0.11 & 1.20 & 23.3 \\
\hline & $\mathrm{T} 1$ & $137.1^{\mathrm{a}}$ & 38.3 & 5.865 & 57.3 & 2.8 & 21.98 & $1453^{b}$ \\
\hline & $\mathrm{T} 2$ & $130.7^{\mathrm{b}}$ & 41.2 & 5.860 & 58.3 & 3.1 & 24.65 & $1420^{\mathrm{b}}$ \\
\hline & $\mathrm{T} 3$ & $122.6^{\mathrm{c}}$ & 40.4 & 4.820 & 60.8 & 2.9 & 25.05 & $1529^{\mathrm{a}}$ \\
\hline Pooled SEM & & 1.9 & 2.29 & 0.348 & 2.07 & 0.34 & 1.48 & 28.5 \\
\hline \multirow[t]{3}{*}{ Dried } & $\mathrm{T} 1$ & 126.9 & 29.0 & 6.822 & $57.2^{\mathrm{a}}$ & 2.4 & 16.56 & $1532^{\mathrm{ab}}$ \\
\hline & $\mathrm{T} 2$ & 121.2 & 27.3 & 7.584 & $53.7^{\mathrm{b}}$ & 2.3 & 14.70 & $1382^{\mathrm{b}}$ \\
\hline & $\mathrm{T} 3$ & 117.6 & 31.3 & 6.015 & $55.9^{\mathrm{b}}$ & 2.6 & 17.63 & $1453^{a b}$ \\
\hline \multirow[t]{3}{*}{ Fresh } & $\mathrm{T} 1$ & 147.3 & 47.6 & 4.907 & $57.4^{\mathrm{a}}$ & 3.3 & 27.40 & $1375^{\mathrm{b}}$ \\
\hline & $\mathrm{T} 2$ & 140.3 & 55.1 & 4.136 & $62.8^{\mathrm{a}}$ & 3.8 & 34.60 & $1458^{\mathrm{ab}}$ \\
\hline & $\mathrm{T} 3$ & 127.3 & 49.3 & 3.625 & $65.7^{\mathrm{a}}$ & 3.3 & 32.46 & $1604^{\mathrm{a}}$ \\
\hline Pooled SEM & & 2.3 & 3.2 & 0.492 & 1.8 & 0.19 & 2.09 & 40.4 \\
\hline \multicolumn{9}{|l|}{ Main Effect } \\
\hline Form & & $<0.0001$ & $<0.0001$ & $<0.0001$ & $<0.0001$ & $<0.0001$ & $<0.0001$ & NS \\
\hline ISS level & & $<0.0001$ & NS & NS & NS & NS & NS & 0.0263 \\
\hline Form x Level & & NS & NS & NS & 0.0367 & NS & NS & $<0.01$ \\
\hline
\end{tabular}

${ }^{\mathrm{a}-\mathrm{c}}$ Means within a row with no common superscript differ significantly $(\mathrm{P}<0.05)$. SEM: standard error of mean. Ducks fed RB 60\%, YC 30\%, SSF $10 \%$ (T1); ducks fed RB 50\%, YC 30\%, SSF 20\% (T2); ducks fed RB 40\%, YC 30\%, SSF 30\% (T3), RB:Rice Bran, YC: Yellow Corn, SSF= Sapu-sapu Fish. NS= Not Significant

Increasing SSF levels did not affect significantly $(\mathrm{P}>0.05)$ on egg production. The $20 \%$ SSF tended to have the higher egg production $(41.2 \%)$ than the $30 \%$ SSF $(38.3 \%)$ with the total egg number/bird/wk was 3.1 eggs. It means that the level protein requirement had been reached with the $20 \%$ SSF containing $14.15 \%$ CP which was the precise requirements for laying Mojosari ducks. The effect of dietary protein on egg production in this study was consistent with
Junqueira et al. (2006) who reported higher protein levels did not have any effect on bird performance.

The interaction of SSF form and levels influenced egg weight and body weight indicated that increased feed intake significantly $(\mathrm{P}<0.05)$ due to SSF fresh and increased protein intake with increased SSF levels (Table 3) which resulted in increased egg weight and body weight. Conversely, the dried SSF reduced feed intake 
Table 3. The Effect of Forms and Levels of SSF on Nutrient Intake of Mojosari Ducks From 24 to 32 Wk. of Age*

\begin{tabular}{|c|c|c|c|c|c|c|}
\hline $\begin{array}{l}\text { SSF } \\
\text { Form }\end{array}$ & $\begin{array}{c}\text { SSF } \\
\text { Level }(\%)\end{array}$ & $\begin{array}{c}\text { Energy Intake } \\
\text { (kcal/bird/d) }\end{array}$ & $\begin{array}{l}\text { Protein Intake } \\
\quad(\mathrm{g} / \mathrm{bird} / \mathrm{d})\end{array}$ & $\begin{array}{l}\text { Crude Fiber } \\
\text { Intake } \\
(\mathrm{g} / \mathrm{bird} / \mathrm{d})\end{array}$ & $\begin{array}{c}\text { Ether Extract } \\
\text { Intake } \\
\text { (g/ bird/d) }\end{array}$ & $\begin{array}{c}\mathrm{Ca} \\
\text { Intake } \\
(\mathrm{g})\end{array}$ \\
\hline Dried & & $373^{b}$ & $18.4^{\mathrm{b}}$ & $15.5^{\mathrm{b}}$ & $6.37^{\mathrm{b}}$ & $2.39^{\mathrm{b}}$ \\
\hline Fresh & & $424^{\mathrm{a}}$ & $21.4^{\mathrm{a}}$ & $18.0^{\mathrm{a}}$ & $7.20^{\mathrm{a}}$ & $2.78^{\mathrm{a}}$ \\
\hline \multirow[t]{4}{*}{ Pooled SEM } & & 3.9 & 0.22 & 0.19 & 0.08 & 0.03 \\
\hline & $\mathrm{T} 1$ & $422^{\mathrm{a}}$ & $15.2^{\mathrm{c}}$ & $19.5^{\mathrm{a}}$ & $5.65^{\mathrm{c}}$ & $1.546^{\mathrm{c}}$ \\
\hline & $\mathrm{T} 2$ & $400^{\mathrm{b}}$ & $20.2^{\mathrm{b}}$ & $17.0^{\mathrm{b}}$ & $6.87^{\mathrm{b}}$ & $2.640^{\mathrm{b}}$ \\
\hline & $\mathrm{T} 3$ & $374^{\mathrm{c}}$ & $24.3^{\mathrm{a}}$ & $13.8^{\mathrm{c}}$ & $7.83^{\mathrm{a}}$ & $3.587^{\mathrm{a}}$ \\
\hline Pooled SEM & & 4.8 & 0.27 & 0.24 & 0.09 & 0.03 \\
\hline \multirow[t]{3}{*}{ Dried } & $\mathrm{T} 1$ & 390 & 14.2 & 18.3 & 5.2 & $1.448^{\mathrm{d}}$ \\
\hline & $\mathrm{T} 2$ & 371 & 18.2 & 15.3 & 6.3 & $2.377^{\mathrm{c}}$ \\
\hline & $\mathrm{T} 3$ & 358 & 22.7 & 12.9 & 7.5 & $3.354^{\mathrm{a}}$ \\
\hline \multirow[t]{3}{*}{ Fresh } & $\mathrm{T} 1$ & 453 & 16.1 & 20.8 & 6.0 & $1.645^{\mathrm{d}}$ \\
\hline & $\mathrm{T} 2$ & 430 & 22.3 & 18.7 & 7.3 & $2.903^{b}$ \\
\hline & $\mathrm{T} 3$ & 389 & 25.9 & 14.7 & 8.1 & $3.820^{\mathrm{a}}$ \\
\hline Pooled SEM & & 6.8 & 0.39 & 0.31 & 0.13 & 0.053 \\
\hline \multicolumn{7}{|l|}{ Main Effect } \\
\hline Form & & $<0.0001$ & $<0.0001$ & $<0.0001$ & $<0.0001$ & $<0.0001$ \\
\hline Level & & $<0.0001$ & $<0.0001$ & $<0.0001$ & $<0.0001$ & $<0.0001$ \\
\hline Form x Level & & NS & NS & NS & NS & 0.0204 \\
\hline
\end{tabular}

a-d Means within a row with no common superscript differ significantly $(\mathrm{P}<0.05)$; SEM: standard error of mean. Ducks fed RB 60\%, YC 30\%, SSF 10\% (T1); ducks fed RB 50\%, YC 30\%, SSF 20\% (T2); ducks fed RB 40\%, YC 30\%, SSF 30\% (T3), RB:Rice Bran, YC: Yellow Corn; SSF= Sapu-Sapu Fish.

*Calculated from feed composition is shown in Table 1 and 2. NS= Not Significant

then reduced body weight which reduced egg weight. Lacin et al. (2008) noted that there was egg weight increased as body weight increased.

In terms of feed conversion, the inclusion levels of SSF in the diet did not affect FCR significantly. Feed conversion ratio was significantly improved from 6.807 to 4.223 with the fresh SSF. The fresh SSF improved FCR because feed intake increased significantly (138.4 $\mathrm{g} / \mathrm{d}$ ) with higher egg mass (31.48 g/bird per day) compared to the dried SSF with lower feed intake
(121.9 g/bird per day) and egg mass $(16.30 \mathrm{~g} / \mathrm{bird}$ per day). This result was consistent with that of Gunawardana et al. (2008) who indicated that a significant increase in protein and energy diets, improved feed conversion significantly as egg weight and production increased significantly. Egg weight and egg production responded in a linier manner to balanced dietary protein level (Shim et al., 2013). This could be achieved in the balance of amino acids of the protein diet which is available from the SSF fresh. 


\section{Egg Quality Assessment}

The results of egg quality parameters measured at 31 and 32 wk of age are depicted in Table 4. It appears that there was no effects of the form of SSF on shell weight, albumen weight, and albumen height but it affected shell thickness, yolk weight, and yolk height and yolk color.

Levels of SSF had no significant effect on all egg quality parameters measured except the shell thickness. There was no interaction between forms and levels of SSF on egg quality parameters. The higher shell thickness observed at higher SSF could be due to the higher Ca intake (Table 3). Birds receiving the $30 \%$ SSF provided $2.62 \%$ dietary $\mathrm{Ca}$ with the average $\mathrm{Ca}$ intake $3.587 \mathrm{~g} / \mathrm{bird} / \mathrm{d}$. This finding closely agreed with Chen and Shen (1989) who reported that for maximum shell quality, 3\% dietary calcium levels was sufficient for laying ducks.

There was no significant effect of SSF forms and levels and their interaction $(\mathrm{P}>0.05)$ on albumen weight and albumen height (Table 4). Thus increasing SSF increased dietary protein levels did not affect on albumen parameters. This

Table 4. Egg Quality of Laying Ducks Fed with Different Forms and Sapu-sapu Fish (SSF) Dietary Levels From 24 to 32 Weeks of Age

\begin{tabular}{|c|c|c|c|c|c|c|c|c|}
\hline $\begin{array}{c}\text { SSF } \\
\text { Form }\end{array}$ & $\begin{array}{l}\text { SSF } \\
\text { Level } \\
(\%)\end{array}$ & $\begin{array}{l}\text { Shell } \\
\text { Weight } \\
\text { (g) }\end{array}$ & $\begin{array}{c}\text { Shell } \\
\text { Thickness } \\
(\mathrm{mm})\end{array}$ & $\begin{array}{c}\text { Albumen } \\
\text { Weight } \\
\text { (g) }\end{array}$ & $\begin{array}{c}\text { Albumen } \\
\text { Height } \\
\text { (mm) }\end{array}$ & $\begin{array}{l}\text { Yolk } \\
\text { Weight } \\
\text { (g) }\end{array}$ & $\begin{array}{l}\text { Yolk } \\
\text { Height } \\
(\mathrm{mm})\end{array}$ & $\begin{array}{l}\text { Yolk } \\
\text { Color } \\
\text { RCF }\end{array}$ \\
\hline Dried & & 7.35 & $0.393^{\mathrm{b}}$ & 27.58 & 8.79 & $20.60^{b}$ & $19.06^{\mathrm{b}}$ & $7.50^{b}$ \\
\hline Fresh & & 7.56 & $0.496^{\mathrm{a}}$ & 27.83 & 10.42 & $24.14^{\mathrm{a}}$ & $22.25^{\mathrm{a}}$ & $9.84^{\mathrm{a}}$ \\
\hline \multirow[t]{4}{*}{ Pooled SEM } & & 0.25 & 0.012 & 1.24 & 0.58 & 0.81 & 1.05 & 0.34 \\
\hline & $\mathrm{T} 1$ & 7.44 & $0.417^{b}$ & 27.09 & 9.46 & 21.54 & 20.65 & 9.00 \\
\hline & $\mathrm{T} 2$ & 7.37 & $0.436^{\mathrm{ab}}$ & 27.50 & 8.47 & 23.05 & 21.30 & 8.00 \\
\hline & $\mathrm{T} 3$ & 7.55 & $0.480^{\mathrm{a}}$ & 28.53 & 10.89 & 22.53 & 20.02 & 9.16 \\
\hline Pooled SEM & & 0.30 & 0.015 & 1.52 & 0.72 & 0.99 & 1.29 & 0.42 \\
\hline \multirow[t]{3}{*}{ Dried } & $\mathrm{T} 1$ & 7.00 & 0.366 & 29.50 & 9.25 & 21.28 & 18.62 & 7.66 \\
\hline & $\mathrm{T} 2$ & 7.81 & 0.356 & 26.85 & 8.84 & 19.68 & 18.58 & 7.00 \\
\hline & $\mathrm{T} 3$ & 7.88 & 0.456 & 27.15 & 13.18 & 20.85 & 19.99 & 7.83 \\
\hline \multirow[t]{3}{*}{ Fresh } & $\mathrm{T} 1$ & 7.88 & 0.468 & 24.68 & 9.66 & 21.80 & 22.68 & 10.33 \\
\hline & $\mathrm{T} 2$ & 6.93 & 0.516 & 28.16 & 8.10 & 26.41 & 24.02 & 9.00 \\
\hline & $\mathrm{T} 3$ & 7.23 & 0.503 & 29.91 & 8.61 & 24.21 & 20.05 & 10.50 \\
\hline Pooled SEM & & 0.43 & 0.022 & 2.15 & 1.01 & 1.40 & 1.82 & 0.59 \\
\hline \multicolumn{9}{|l|}{ Main Effect } \\
\hline Form & & NS & $<0.0001$ & NS & NS & 0.004 & 0.041 & $<0.0001$ \\
\hline Level & & NS & 0.0264 & NS & NS & NS & NS & NS \\
\hline Form x Level & & NS & NS & NS & NS & NS & NS & NS \\
\hline
\end{tabular}

${ }^{\mathrm{a}-\mathrm{c}}$ Means within a row with no common superscript differ significantly $(\mathrm{P}<0.05)$. SEM: standard error of mean. Ducks fed RB 60\%, YC 30\%, SSF $10 \%$ (T1); ducks fed RB 50\%, YC 30\%, SSF $20 \%$ (T2); ducks fed RB 40\%, YC 30\%, SSF 30\% (T3); RCF (Roche Color Fan), RB:Rice Bran, YC: Yellow Corn; SSF= SapuSapu Fish, NS= Not Significant 
is in agreement with that of Anwar et al. (2015) who found that albumen weight and albumen were not affected by dietary protein levels.

In relation to yolk parameters, the fresh of SSF significantly affect $(\mathrm{P}<0.05)$ on yolk weight, yolk height and yolk color. However, the levels of SSF did not affect all these characteristics. There was no interaction between the SSF form and levels. Yolk color was measured as an indicator of egg quality and provided for desirable consumer preferences. With similar levels of yellow corn (30\%) imposed in this study (Table 2), yolk color reached 9.84 and 7.5 RYCF in fresh and dried SSF respectively (Table 4). Corn has been known as carotenoid and xanthophyll sources to improve yolk pigmentation. In a diet containing corn, pigmentation in egg yolk was in linier with the levels of corn portion used in the diet (Ghazvinian et al., 2011; Kljak et al., 2012). Rashid et al. (2004) used 58 and $67.5 \%$ corn in the diet, yolk color score obtained were $8.58 \pm 1.70$ and 5.9 \pm 1.81 . Laganá et al. (2011) reported feeding $32.24 \%$ corn in sorghum and soybean meal based diet without pigment supplementation, yolk color was from 6.5 to 4.0 from day 0 to 28 of observation. As laying birds cannot synthesize egg yolk pigments, egg yolk color strongly depends on the fat-soluble pigments in the diets fed (Gunawardana et al., 2008; Kljak et al., 2012). Increasing egg yolk color was influenced by the added dietary fat and xanthophylls as the major color agent is highly fat soluble (Gunawardana et al., 2008). However, it might be possible that high carotenoid contents of corn were more dominant to control the pigmentation than the energy levels (Moghaddam et al., 2012). In our study, since the fat content of the fresh fish was higher than that of the dried and SSF fat content was also higher than common fish meal (NRC, 1994), increasing the fat content in the diet means increasing xanthophylls may be deposited.

\section{CONCLUSION}

The current study demonstrate the potential SSF as a single protein source in rice bran and yellow corn based diets to replace common fish meal for laying Mojosari ducks which is evidenced by improving egg production. The fresh SSF form inclusion at the level of $20 \%$ can be used to provide the highest egg production. The high inclusion of fresh SSF in the corn-rice bran based diet is possible to improve egg yolk pigmentation and shell thickness

\section{ACKNOWLEDGEMENT}

Authors to thanks to the Directorate General of Higher Education through the Competitive Fund of MP3EI (Masterplan for the Acceleration and Growth of Indonesian Economic Development 2012-2025).

\section{REFERENCES}

Akintola, S.L., A. Brown, A. Bakare, O.D. Osowo and B.O. Bello. 2013. Effects of hot smoking and sun drying processes on nutritional composition of giant tiger shrimp (Penaeus monodon, Fabrisius, 1798). Pol. J. Food Nutr. Sci. 63: 227-237.

Akinwumi, F.O., M.E. Fesobi, I.O. Akinwumi and A. A. Adejuyigbe. 2011. Effects of sun and oven drying on the proximate value of African mud catfish, Clarias gariepinus (Siluriformes: Clariidae). Adv. Food and Ener. Sec. 1: 29-35.

Aktar, M., M. Rashid, M.G. Azam, M.A.R. Howlider and M.A. Hoque. 2011. Shrimp waste and marine waste as substitutes of fish meal in broiler diet. Bang. J. Anim. Sci. 40: 18-22.

Anwar, S.A., M.M. Hady, R.A. Elbanna, and T.M. Melegy. 2015. Impact of reduced protein diets based on ideal amino acid profile on performance and egg quality traits of laying hens. Int. J. Sci, Technol. and Manag. 4(4):220-229.

AOAC International. 1990. Official Methods of Analysis. $15^{\text {th }}$ ed. Washington, DC: Association of Analytical Chemist.

Bunchasak, C., K. Poosuwan and R. Nukraew. 2005. Effect of dietary protein on egg production and immunity responses of laying hens during peak production period. Int. J. Poult. Sci. 4 (9):701-708.

Chen, W.L. and T.F. Shen. 1989. Comparative studies on the utilization of calcium between laying Tsaiya ducks and Leghorn hen. Asian-Aust. J. Anim. Sci. 2:67-75.

Dong, N.T.K., K. Elwinger, J.E. Lindberg and R.B. Ogle. 2005. Effect of replacing soyabean meal with soya waste and fish meal with ensiled shrimp waste on the performance of growing crossbred ducks. Asian-Aust. J. Anim. Sci. 18:825-834.

Falayi, B.A., S.O.E. Sadiku and J.O. Ogedengbe. 2013. Effect of substituting fish meal with sesame cake seed on growth and feed 
utilization of African mud fish. Adv. Res. Biol. Sci. 1: 31-35.

Ghazvinian, K., M. Irani, R. Jamshidi, A. MirzaeiAghsaghali, S.A. Siadati and A. JavaheriVaighan. 2011. The effect of energy to protein ratio on production performance and characteristics of Japanese quail eggs. Annals of Biol. Res., 2: 122-128.

Gunawardana, P., D.A. Roland, $\mathrm{Sr}$ and M.M. Bryant. 2008. Effect of energy and protein on performance, egg components, egg solids, egg quality, and profits in molted HyLine W-36 Hens. J. Appl. Poult. Res. 17: 432-439.

Hassan, A.A., I. Sani, M.W. Maiangwa and S.A. Rahman. 2009. The effect of replacing graded levels of fishmeal with grasshopper meal in broiler starter diet. Prod. Agric. Technol. 5:30-38.

Jeyasanta, K.I., S.I. Jeyanth Allwin and J. Patterson. 2014. Quality characteristics of traditionally sundried fishes for poultry feed in tuticorin, South East Coast of India. Br. J. Poult. Sci. 3:49-61.

Junqueira, O.M., A.C. de Laurentiz, R. da Silva Firaldi, E.A. Rodrigues and E.M. Casartelli, .2006. Effects of energy and protein levels on egg quality and performance of laying hens at early second production cycle. J. Appl. Poult. Sci. 15: 110-115

Kljak, K., M. Drdić, D. Karolyi and D. Grbeša. 2012. Pigmentation efficiency of Croatian corn hybrids in egg production. Croatian J. Food Technol., Biotechnol. and Nutr. 7 (Special Issue): 23-27.

Lacin, E. A. Yildiz, N. Esenbuga and M. Macit. 2008. Effects of differences in the initial body weight of groups on laying performance and egg quality parameters of Lohmann laying hens. Czech J. Anim. Sci. 53(11): 466-471.

Laganá, C., C.C.Pizzolante, E.S.P.B. Saldanha, J.E de Moraes. 2011. Turmeric root and annato seed in second-cycle layer diets: performance and egg quality. Braz. J. Poult. Sci. 13: 171-176.

Moghaddam, H.N., M. Kazemi Fard, M.J. Agah, S.J. Hosseini and M.T. Mirakzehi. 2012.
Effect of different levels of methionine, protein and tallow on the productive performance and egg quality of laying hens in the late-phase production. Braz. J. Poult. Sci., 14: 149-158.

National Research Council (NRC). 1994. Nutrient Requirements of Poultry. Ninth Revised Edition. National Academy Press, Washington, D.C.

Onwudike, O.C. 1981. Effect of various protein sources on egg production in a tropical environment. Trop. Anim. Prod., 6: 249-256.

Rashid, M.M., M.N. Islam, B.C. Roy, K. Jakobsen and C. Lauridsen. 2004. Effect of dietary supplementation of energy and protein on production performance and egg quality of scavenging crossbred hens in rural areas under tropical conditions. Livestock Research for Rural Development. Vol. 16, Art. \# 63. Retrieved September 30, 114 from http://www.lrrd.org/lrrd16/8/rash16063.htm

Roosmini, D., Rachmatiah, I., Suharyanto, A. Soedomo and F. Hadisantosa. 2006. Biomarker as an indicator of river water quality degradation. J. Eng. Technol. Sci., 38: 114-122. DOI: http://dx.doi.org/10.5614\%2Fitbj.eng.sci.20 06.38.2.3

SAS Institute. 1999. SAS ${ }^{\circ}$ user's guide: Statistics, Version 8. SAS Institute Inc., Cary, NC., USA.

Shim, M.Y., E. Song., L. Billard, G.M. Pesti and P. Sodsee. 2013. Effects of balanced dietary protein levels on egg production and egg quality parameters of individual commercial layers. Poult. Sci. 92(10):2687-2696.

Tarasewicz, Z., D. Szczerbińska, M. Ligocki, D. Wiercińska, D. Majewska and K. Romaniszyn. 2006. The effect of differentiated dietary protein level on the performance of breeder quails. Anim. Sci. Papers and Reports. 24: 207-216.

Thongwittaya, N. 2007. Substitution of plant protein for fish meal in laying ducks. Anim. Sci. J., 78: 351-355.

Wimalasena, S. and M.N.S. Jayasuriya. 1996. Nutrient analysis of some fresh water fish. J. Natn. Sci. Coun. Sri Lanka. 24: 21-26. 